\title{
Keeping it Country while Dancing with the Elite
}

\author{
Stian Vestby \\ Inland Norway University of Applied Sciences \\ stian.vestby@inn.no
}

\begin{abstract}
This article examines programme and audience development at the "Norwegian Country Meeting" after this festival achieved status as a Norwegian hub festival for country music in 2012. Building on ethnographic data, this article focuses on the effects cultural policies and authoritative criteria for aesthetic quality have had on a popular musical event. The results show how cultural policy may be operationalized based on the dominating preferences of the cultural elite. In this context 'musical gentrification' (Dyndahl et al. 2014), a structural phenomenon in which low culture is absorbed into the legitimate culture with inclusionary and exclusionary outcomes, becomes a central theoretical concept. The significance of the study is reflected in its descriptions of how cultural practices and policies relate to wider systems of power and socio-aesthetic inequality.

KEYWORDS: Country music, Festival audiences, Class distinctions, Cultural policy, Quality judgements, Musical gentrification
\end{abstract}

\section{Introduction}

In a sociological study from 2014, Ljunggren asks whether there exists a Norwegian cultural elite. Building on interviews with individuals rich in cultural capital and with prominent positions in cultural and educational fields, he finds that "the cultural elite is obviously more than just a myth or an elite 'on paper'" (Ljunggren 2014: 208, my translation). According to Ljunggren, affiliation with the centralized Norwegian cultural elite depends on three criteria: profession(al position), public visibility, and power. Most of the interviewees reported that they feel they have considerable influence on how education, cultural expressions, and public debates are shaped and controlled (ibid.).

Post-World War II Norway is one of the world's most well-off and egalitarian societies (OECD 2017). The benefits of general access to free education and cultural participation have contributed to a situation where upward class mobility and social equality are widespread. However, recent research shows that class distinctions continue to play a role in Norwegian social democracy (Dyndahl et al. 2016; 
Jarness 2015; Korsnes et al. 2014). As indicated above, this is certainly true in the field of culture, where class conflicts permeate aesthetic judgements and other common practices such as musical listening and festival attendance. In a report on the 'democratization of culture' by way of cultural policy, Mangset (2012: 49, my translation) concludes that "even if the society is changing, significant social differences in cultural consumption have a tendency to be sustained".

If the cultural elite typically consists of urban, hip, and culturally sophisticated representatives functioning as arbiters of good taste; popular belief holds that the country class represents ill-behaving rural rednecks with vulgar cultural tastes. Playing with myths, one might even say that country music is abject culture and bad music, while the music and culture of the elites are decent and good. However, as stated by Fox (2004a), country music in the US can be both working-class and middle-class culture. In Norway country music can indeed also be elite culture (Vestby 2017). Hence, the Norwegian field of country music can be seen as an arena for conflicts between its popular and distinguished participants. These participants consist of performers, organizers, journalists, cultural policy stakeholders, and audience segments often defined as hip or redneck.

The annual music festival Norsk Countrytreff (the "Norwegian Country Meeting", abbreviated NCT), located in rural Breim in Western Norway, is an arena facilitating meetings between these participants. Following Bourdieusian theory, the festival setting may be viewed as a field of country music experiences. Another interlinked battlefield consists of discursive utterances about the festival in, for instance, the national media and in policy documents.

The overall aim of this article is to explore empirical effects and structural implications of 'musical gentrification' (Dyndahl et al. 2014) in the case of a statefunded country music festival, namely NCT. In this context, the term musical gentrification refers to the inclusion of country music in a cultural policy support scheme known as Knutepunktordningen (the "hub scheme") for leading cultural festivals/institutions in Norway. The concept of musical gentrification is derived from Bourdieu's theories, but expands on his ideas by referring to a structural phenomenon in which traditional low culture is absorbed into the legitimate culture with various inclusionary and exclusionary outcomes. The subsequent ethnographic analysis illustrates how taste, distaste, and socio-aesthetic inequality are articulated across the two aforementioned fields.

\section{Background}

In competition with two other country music festivals, NCT was granted status as a hub festival for country music in 2012 . The festival retained this status and received approximately 1.7 million NOK (Norwegian kroner) annually over the National Budget until 2016/2017, when the hub scheme was fused into and gradually replaced by a new national support scheme for festivals (Vestby 2017). As part of Norwegian cultural policy, the hub scheme was in operation for more than twenty years. While the Ministry of Culture allocated money to hub festivals/institutions, Arts Council Norway (ACN), "the main governmental operator for the implementation of Norwegian cultural policy" (ACN 2018), assessed applicants and existing hubs based on artistic criteria. This work followed the 'arm's length' principle of autonomous decision making, which secures some distance from the ruling political authorities (cf. Hylland and Stavrum 2018).

By 2015 there were sixteen national hub institutions in Norway, of which twelve were music festivals. The genre hierarchy inherent in the hub scheme was twofold. 
First, the genres and artistic fields that were initially included in the scheme represented high culture. As early as the 1990s, various classical music festivals had received hub status, and by the turn of the millennium, jazz, long established as a musical genre of considerable status in the legitimate culture, became the first popular music hub. Further expansion followed with the inclusion of, for instance, folk and world music, blues, rock, and, finally, country music. Second, the genre hierarchy was reflected in the annual funding allocated to each hub festival. The discrepancy in allocations to Festspillene i Bergen ("Bergen International Festival") and NCT in 2015 may serve as a telling example. While the former received some twenty million NOK for this year, the latter received less than two million (Vestby 2017).

As Minister of Culture, Anniken Huitfeldt (Labour) proposed that the country genre be given its own hub festival. By granting NCT status as a national hub for country music alongside other already gentrified musical genres, Norwegian officialdom gave recognition to this often-undervalued genre and musical culture to an unprecedented degree. Moreover, the Minister declared that "[g]enre chauvinism in cultural policy has definitely come to an end with the establishment of this national hub" (Norwegian Ministry of Culture 2011, my translation), signalling that this act was of great symbolic significance also for the nation's cultural policy.

The Minister's statement is sympathetic and inclusive with regards to the country music community. It also points back to a general trend in Norwegian cultural policy throughout the previous three decades, intensified in the period of the Centre-Left government from 2005 to 2013, of including and allocating funds to more and more popular music expressions (Brandstad 2002; Henningsen 2015). Despite this expansion, the statement discredits important popular genres such as Scandinavian dance band music and electronic dance music by excluding them from the hub status discussion. Much like country, jazz, and classical music, these genres also have festivals catering to niche audiences.

Solli (2006) discusses the genre hierarchy in Norwegian cultural policy at the turn of the millennium by comparing country and jazz. During this period, the Norwegian state contributed to the spread and institutionalization of jazz by including the genre in official policies, partly in an effort to build national identity. Norwegian jazz was civilized and sophisticated enough for Norway's cosmopolitan self-portrait, while country was not. As Solli (2006: 222) points out: "[t]he 'abject' Norwegianness of country music festivals, for example, is a form of 'counter culture' that rejects the middle-class ideals projected by 'good society'". Country music's often rural, conservative, working-class content and image, have long been a source of disdain and bigotry both in the US (Ching 2001; Hubbs 2014) and in Norway (Solli 2006; Vestby 2017). Recent developments may, however, indicate a change towards more positive upper-class involvement with country music in Norway. Country, bluegrass, Americana, and Nordicana (Zimmerman 2018) are currently thriving, especially in the capital city of Oslo where hip and resourceful musicians and other cultural operators have taken possession of these musical forms. Several credible artists have performed at rural NCT, some prior to, some during, and some after its period as a hub festival. Many of the festival's performers, however, typically fall into more stigmatized categories, such as country/dance band crossover, Norwegian party country, cover bands, conservative and irrelevant music - basically various expressions of non-credible bad music (Fox 2004b; Frith 2004). 


\title{
Musical gentrification, (dis)taste, and country music
}

'Musical gentrification' first appeared in the context of Norwegian music academia in 2012 when the research project Musical Gentrification and Socio-Cultural Diversities was in its preparatory stages. In a key publication from the project, the authors define musical gentrification as:

\begin{abstract}
complex processes with both inclusionary and exclusionary outcomes, by which musics, musical practices, and musical cultures of relatively lower status are made to be objects of acquisition by subjects who inhabit higher or more powerful positions. (...) $[T]$ hese processes strongly contribute to changing the characteristics of particular musical communities as well as the musics, practices, and cultures that are subjected to gentrification. (Dyndahl et al. 2014: 54).
\end{abstract}

The authors make reference to the original notion of gentrification as employed within urban sociology/geography/law (Glass 1963; Marcuse 1985) and city planning discourses. Two central aspects of gentrification are: (1) the upscaling or refinement of traditional, working-class areas/neighborhoods; and (2) various forms of displacement of the original residents of those areas/neighborhoods. Transferred into the field of music, these features become part of Dyndahl et al.'s theory. In line with Halnon and Cohen (2006: 35-36), who evoke a similar concept of socioaesthetic gentrification, one may in the present context speak of "the 'symbolic neighborhoods' of the lower classes in popular culture (...) in which the economically fragile middle classes continue to distinguish themselves with the 'victorious' 'aesthetic' consumption of lower-class symbols". Peterson and Kern (1996: 906) explain in similar terms how 'cultural omnivores' typically "gentrify elements of popular culture and incorporate them into the dominant status-group culture". Structural gentrification processes are thus often double-sided, that is with inclusive and exclusive results, as distinction is the central, underlying factor at the micro level of cultural practice: "[T] astes are perhaps first and foremost distastes, disgust provoked by horror or visceral intolerance ('sick-making') of the tastes of others" (Bourdieu 1979[2010]: 49). Hence, gentrification through refinement of and aesthetic involvement with, for instance, working-class musical expressions enables such popular forms to enter legitimate culture.

The notion of musical gentrification builds on Bourdieu's theory of practice and interweaves with central concepts such as habitus, 'capital', doxa, and 'field' as epitomized in his influential work on classed taste (ibid.). Social fields are arenas where agents and institutions compete for symbolic goods and positional legitimacy that are regulated by field-specific social conventions and beliefs (doxa), habitus and capital forms. The habitus of an agent is largely made up of collective, or classed, modes of seeing and acting in the world. Moreover, one of Bourdieu's capital forms, 'cultural capital', consists of dispositions and competences inherent in an agent's habitus, and of various cultural resources and products pertinent to a specific field (ibid.). While some works of art, for instance musical, are considered pure and require an aesthetic disposition/educated mode of appreciation, other art works are deemed vulgar and thus reflections of the grotesque tastes and modes of appreciation favoured by the uneducated (Bourdieu ibid., 1993). These opposing qualities and practices align with what I, in the analysis, label 'deep listening' and 'bodily listening'. The initial term also connects with the notion of 'didactic cosmopolitanism' (Vestby 2017). As these classifications are grounded in and developed from the context of live music experiences at NCT, the terms will be illuminated further in the following analytical portraits of this empirical field. 
Peterson (1995[2004]) indirectly addresses the phenomena of (dis)taste in his theory of the 'hard-core' and 'soft-shell' dialectic in North American country music. This rough classification encompasses country music's many styles and expressive forms, and includes sets of musical traits and signifiers that can be read as cultural dichotomies. Examples of such hard-core and soft-shell binaries include rural/urban, personal/impersonal, informal/formal, masculine/feminine, workingclass/middle-class, and authentic/inauthentic (ibid.; see also Ching 2001; Hubbs 2014). Peterson's classification serves to explain the historical development and reception of country music, focusing on the cyclical and dialectical appearance of musical reactions and counter-reactions, in the US music market. He shows how the appearance and popularity of a rustic and relatively homogeneous hard-core style typically is followed by the flourishing of a pop-oriented and relatively heterogenous soft-shell style, before hard-core country music again resurfaces and dominates.

The present study departs from Peterson's dialectical and diachronic perspective, and recontextualizes the hard-core/soft-shell dichotomy in synchronic analyses of contemporary country music performances in Norway. In the musical and social aesthetics of the selected artists, conventional sonic traits and cultural signifiers commonly found in US country music are appropriated alongside locally produced musical additions. Identified in their natural context, these features connect in complex ways with musical gentrification.

\section{A festival ethnography}

The empirical data on which the present ethnographic analysis is based were collected through qualitative and quantitative methods, initially as part of a PhD study (Vestby 2017) belonging to the Musical Gentrification and Socio-Cultural Diversities research project. The methods include field observations at NCT in 2013, 2014 and 2015; semi-structured interviews with anonymized festivalgoers, organizers, and the then Minister of Culture; a quantitative survey among 119 attendees at NCT 2014; and close readings of central cultural policy documents and media texts, as well as live and recorded musical material gathered mostly during fieldwork.

The data chosen for this article have been organized, examined, and triangulated to ensure sound descriptions and interpretations. Designed as an ethnographic case-study, focusing on a few selected concert formats at NCT, the following analysis employs strategies of 'verisimilitude' (Angrosino 2007) and 'thick description' (Geertz 1973) in an attempt to convey some of the contextual richness of the experiential and discursive fields in question, and also how relevant cultural practices and policies relate to wider systems of power and socio-aesthetic inequality.

\section{Popular and distinguished communities}

Historically, and in line with Storey's (2003) notion of popular culture as the other of high culture, country music may be viewed as the other of serious/art music. Aesthetically, it may of course be argued that country music represents an art form (Tichi 1994). However, from the perspective of the US music industry, Peterson (1997: 7) classifies country music as a "commercial market form 'in the middle' without being 'absorbed' into popular music, 'elevated' into art, or 'ossified' as a folk music". Ching (2001) and Hubbs (2014) acknowledge the commercial 
character of much country music. They emphasize the widespread disidentification with country music found among America's middle and upper classes, making it "a taste apart" (Hubbs 2014: 41). For several decades, the othering of country music in Norway has probably been strengthened from within the popular country music field itself partially through counter-cultural festival practices (Solli 2006). Hence, when an attempt is made to elevate, institutionalize, and gentrify country music by way of cultural policy and elite investment, as was the case with NCT, who is able to keep it country amidst the expected refinement and consecration?

During my three years of fieldwork at NCT, the festival presented artists belonging to a wide range of styles affiliated with the country music genre. Employing Peterson's (1995[2004]) distinction between hard-core and soft-shell country music, artists whose aesthetic expressions and modes of performance lean towards the hard-core, were dominant (fieldnotes July 2013, July 2014, July 2015). According to this classification, hard-core country music typically involves near, informal, and rural/rustic qualities, while soft-shell country music contrastingly involves distanced, formal, and urban/glossy features. In musical expressions belonging to the first category, vocal and instrumental twang (Mann 2008) are often paired with discernible respect for the roots of country music. The perceived authenticity of hard-core country music thus finds its counterpart in what may be deemed inauthentic soft-shell country music. Here the use of standard pronunciation, mainstream singing and playing styles, and hybrid/crossover approaches are more common (Peterson 1995[2004]).

To be able to construct and signify a hard-core country music identity, certain musical signifiers, values, and modes of behaviour need to be put into practice. In country music culture, in addition to appropriating the abovementioned hard-core elements in songs and stage performances, keeping it country would generally also involve wearing cowboy and cowgirl attire; drinking and partying; dancing; singing or thinking about love and loss, sin and redemption, compassion and despair, all enveloped in nostalgia, traditional gender views, and family concerns (Malone and Neal 1968[2010]). Lyrically, country songs "describe life as it is, not as one might wish it would be (...) and remind the listener that his or her private pain has been felt by other people" (ibid.: 298, 301). Hence, the coherence between artist and audience authenticity is a principal matter in the field of country music.

\section{Outdoor country fest and bodily listening}

It is mid-July, $5 \mathrm{pm}$. The sun appears from behind the clouds hovering over the river valley. The weather is unseasonably cold. A massive mountain ridge, partly covered in snow, overlooks the festival site and camping grounds. The NCT main stage and dancing area are empty. At the moment the activity is going on elsewhere. Many guests are seated by their caravans decorated with American and Norwegian flags, or outside their tents where they barbecue and enjoy each other's company whilst trying to keep warm. Some 150 spectators have gathered by the small stage. They enjoy food and drinks; they laugh and talk. Many are dressed in cowboy hats and boots, fringe jackets and denim, and other Western gear, contributing to the overall country flavour of this cultural space. The pioneering Norwegian country/Americana artist, Claudia Scott, is entertaining the audience. Some attendees are clearly there for the music, keeping a steady focus on Scott and her band. Others do not bother so much about the performance. Musical and social functions often work side by side at popular festivals. The hub festival for country music is no exception (fieldnotes and visual data 10 July 2014; survey 2014).

Unlike Scott, the Norwegian party country band Vassendgutane (the "Water-End Boys") are regulars at NCT. From 2004 to 2015 the band performed at the festival 
nine times. When NCT was selected as the national hub festival for country music, author and cultural critic Vidar Kvalshaug declared:

A government-supported festival cannot have Vassendgutane as headliner or give access to more and more of the dance band community, as we have seen in recent years. There is an infinite distance between international quality country music and Norwegian dance band music. (Kvalshaug 2011, my translation).

The fact that a member of the centralized cultural elite devalues a rural, workingclass country band such as Vassendgutane and challenges the legitimacy of the new country music hub festival, is only natural. Vassendgutane's take on country music is self-consciously rough and humorous, often in male-chauvinistic ways. And at popular festivals many of their fans ritualistically engage in 'bodily listening', which is quite the other of the aesthetic mode of listening, or 'deep listening', typically favored by the cultural middle class and elite (see below).

One unemployed working-class festivalgoer explains that Vassendgutane play a kind of "West Norwegian music that one can recognize oneself in (...) and if you have also listened to the songs in advance, the live concert experience becomes much greater" (Annlaug 2015, my translation). The familiar lyrical content and singalong factor are important to other NCT attendees as well. Another frequent guest also speaks of the masquerade element which is common at this and similar festivals. She explains that they mix cowboy and cowgirl attire with animal costumes and other props. Working in the public sector, this lower middle-class attendee highlights that the festival frame provides a treasured alternative to her daily routines and modes of behaviour (Hilde 2015).

During Vassendgutane's headliner set, moaning pedal steel tones, twangy Telecaster licks, and nasal vocals pour from the PA system. Rich accordion sounds reminiscent of Norwegian folk and dance band music blend into the soundscape, providing warmth in the cold summer night under the mountain ridge. The band's joy in playing and their cheerful interaction with the NCT audience are easily detectable. They trigger the large crowd consisting of cowboys and cowgirls, but also people wearing all-weather jackets and sneakers. There is "lots of joy in the audience - people who smile, sing along, move their bodies, hold each other, kiss and make out, and many who dance" (fieldnotes 11 July 2014, my translation). Together these forms of bodily listening and related socio-aesthetic practices form a collective ritual, a 'cowboy carnival' (cf. Bakhtin 1965/1984). Together they constitute a meaningful musical spectacle and intertwine with the silently working doxa (Bourdieu 1979[2010]) in the field of country music experiences at NCT. For agents belonging to this popular community these manifestations mirror the rules of the game, not the exceptions.

The excitement and sense of communion taking place would not have been possible without the delivery of a grassroots hit parade. Demonstrating their own twist on country music's hard-core vocal twang, Vassendgutane use their characteristic West Norwegian dialect to convey lyrics that speak of the local to the local, for instance in the song "Granada" (Bare Bra Musikk 2005, excerpt, my translation):

There's no problem getting good-looking women inside,

if you drive a Granada 2,8 Ghia i

With whore lights in the ceiling,

a Cerwin Vega sub in the trunk behind

It pumps when I drive by

Yeah, I'm playing country for the women inside (...) 
The song's lyrics describe a male-chauvinistic redneck culture found in many regions in Norway. Cars, girls, and country music are recurring elements in the song, just as they are in the real lives of many participants in such cultures. Certainly, the narrative is provocative: a well-equipped, young man luring local girls into his pimped-up car, applying rather discourteous imagery ("whore lights"). It reduces women to sex objects and encourages masculine domination. However, this music and its lyrical content seem to resonate well with significant listener segments in Norwegian working and middle-class populations. Party country fans report that the stories told in the songs of Vassendgutane and similar bands are often deeply grounded in the lives of regular people with rural backgrounds. This kind of music connects with a history of popular rural music and dance traditions, to which the late Norwegian party country pioneer, Teddy Nelson, contributed greatly in the seventies and eighties. It also exposes trivial yet meaningful features of authentic life in the Norwegian countryside (Annlaug 2015; Eirik 2015; Hilde 2015). This version of Norwegian hard-core country music thus reflects local aesthetics, history and culture in meaningful ways, despite their sometimes simple and abject messages. Surprisingly maybe, more female than male audience respondents indicate preference for party country, and it appears that this style is popular especially among attendees who have not begun or completed higher education (survey 2014). Looking beyond the lyrical example above, the subtle nuances and full coherence of this music probably ring true in the habitus of these redneck fans. Rather than engaging with the music in a distanced or aesthetic manner, and appreciating its artfulness, the bodily listening witnessed at NCT represents a ritual celebration and revaluation of various earthy, humorous, chauvinistic, and vulgar aspects of ordinary people's lives. Much in line with Fox (2004b: 56), the music of Vassendgutane is "a brilliant way of re-valuing trash, of making the 'bad' song, bad feelings, and the bad modern ('redneck') subject not only good, but sublimely good".

\section{Indoor barn concert and deep listening}

One kilometer away from the main festival arena, on a small farm under the mountain, lies an old barn. Painted in red and white and maintaining a traditional surface, a closer look reveals that this old structure has been repurposed to host a special concert at NCT, now reestablished as a national hub festival. The title of the concert is Blågras ("Bluegrass"). The hostess is Sigrid Moldestad, an acclaimed Norwegian folk musician and singer-songwriter and a native of Breim, the 'home' of the country festival.

Not long before the Blågras ensemble makes its appearance, 200 concertgoers seated on small chairs organized in tight rows engage in small-talk, gaze at the rustic interior of the old building, and look with anticipation towards the stage. Flanked by high-end PA equipment and discreet blue lighting on the worn timber walls, the stage itself is just an opening in the attendees' field of view. It is not elevated. The distance between the stage and the auditorium is minimal. However, those seated in the back rows will have trouble seeing the performance. Listening becomes all the more important (fieldnotes and visual data 12 July 2014).

The organizational and musical collaborations resulting in three successive Blågras concerts at NCT were heavily dependent on hub scheme funding. Other new concert formats were established after the festival was granted hub status, for instance an opening concert and a talent competition, in efforts to fulfil central hub status/cultural policy criteria (Festival representative B 2014; Festival representative C 2014). The profile of Blågras was, however, most clearly tailored to meet the two 
central criteria stated in the hub mission white paper: 'artistically leading' and 'innovative and development oriented' (Norwegian Ministry of Culture and Church Affairs 2008). In the introduction to one of these concerts Moldestad (2014b, my translation) describes it as a meeting "between music, traditions, and musicians that all have given root to what has become the country music genre". Indeed, Blågras represents an innovative musical setting where folk and country musicians from Scandinavia, Britain, and the US work, learn, and perform together.

Inside the barn an eclectic group of musicians forming the 2014 Blågras line-up, get ready to perform Dolly Parton's classic country hit "Coat of Many Colors" (RCA 1971). Their version (Moldestad 2014a) departs from Parton's original interpretation in distinct ways, for instance regarding vocal delivery, instrumentation, and the arrangement. A rhythmic guitar pattern utilizing the harmonic effects of open strings introduces the Blågras version. A Celtic-sounding flute melody appears twice in the arrangement, adding a sonic link to the country genre's formative history. The allacoustic ensemble Moldestad has put together employs dynamic changes and rhythmic variations carried out with sophistication. This is 'chamber country music' intended to exceed the conventions of the genre. So far, key parts of the sonic and cultural palette imbued in this performance of "Coat of Many Colors" manifest a certain mildness, playfulness, and level of refinement that can be associated with soft-shell country music (Peterson 1995[2004]). Naturally it shares a rural situatedness with Parton's original execution, which constitutes one of several characteristic hard-core traits (ibid.). This is audible in the 1971 recording, in which the arrangement and instrumentation are more straightforward and stylistically coherent with traditional country music. Parton conveys lyrical themes of family, upbringing, poverty, and faith with a quite edgy and hard vocal style. The singer's roots in Appalachia are reflected as she employs Southern twang in the words and, with a delicate vibrato and frank clarity in her voice, invites the listener into her personal life and upbringing. Back on stage during Blågras' rendition of "Coat of Many Colors", the centre of attention is Kim André Rysstad, a Norwegian folk musician and singer, whose vocal delivery does not attempt to copy that of Parton. Rysstad provides a contrast to the rough and intimate interpretation of the original artist. The grain of his voice is mild, airy and rich; pleasant to listen to and moving in its own right. He holds a book with the lyrics in front of him as if reading someone else's story. Rysstad pronounces the words in standard American-English, adding a layer of generic distance to his performance. Within this soft-shell draping (ibid.), the ones who vocally keep it country are the background singers, who provide sharper and slightly nasal harmonies in the song's chorus (fieldnotes, audio data and visual data 12 July 2014).

The stigmatized country music and grassroots culture that serve to exclude the cultural elite, are absent at the barn concert. Here country and folk music traditions are reconfigured and presented as something sophisticated and inclusive to more distinguished class representatives. The explorative aims of the Blågras concept and the 2014 ensemble's hybrid version of "Coat of Many Colors" exemplify this socioaesthetic profile. At Blågras concerts attendees wear light, summerly clothes, and appear decent and civilized. Western outfits are practically invisible. Some guests try a locally produced snack or craft beer sold at the venue (fieldnotes and visual data July 2013, July 2014, July 2015). Among survey respondents who attended the Blågras concert in 2014, 62\% report having completed either a bachelor's or master's degree. By comparison, $31 \%$ of the respondents who attended main arena concerts the same year said they had completed a degree in higher education (survey 2014). Lastly, the 'bodily listening' that dominates the main arena is 
substituted with 'deep listening', including more modest, reflexive and educationally oriented modes of interaction and appreciation inside the barn. Hence, there are several indications that the Blågras audience generally belong to the upper or cultural middle class (see also Meisingset 2013), some possibly to the cultural elite. At least they seem to engage in lifestyle practices, share value sets, and follow social conventions that are legitimate within these groups (cf. Bourdieu 1979/2010; Jarness 2015). Respondents and interviewees who either attended Blågras or signalled preference for Moldestad's musical project, confirm this view partly by attaching value to a variety of cultural expressions and displaying a wish to discover and learn about new artists and genres; and partly by expressing concern over government policies aimed at reducing financial support to art and culture, including less commercial, niche-oriented forms and events (Bjørn 2015; Kristian 2015; survey 2014).

According to Dyndahl et al. (2014: 53), musical gentrification provides arenas or fields "for omnivorousness to be exercised according to the need to accumulate and exchange cultural capital in new, differentiated, yet distinguished ways". In this context, Norwegian cultural policy might, as an initial result of gentrification, be viewed as increasingly 'omnivorous' (cf. Peterson 2005; Peterson and Kern 1996) given the inclusion of country music in an important funding scheme. Indeed, 'omnivorousness' appears to be the preferred doxa of musical taste and a valued form of field-specific capital in many social fields. A similar concept is that of 'cultural cosmopolitanism' (Szerszynski and Urry 2002), which also emphasizes tolerant and reflexive preferences and practices. Thus, one may, for instance in the context of music festivals, speak of 'musical omnivores' and of 'musical cosmopolites', the former oriented more towards cultural consumption, and the latter more towards informal learning, implicating what I refer to as 'didactic cosmopolitanism' (Vestby 2017) below.

People learn, consciously or unconsciously, when they engage with (popular) music. As opposed to formal schooling and learning, a public music festival like NCT represents an arena for informal learning (cf. Karlsen 2007). Furthermore, NCT applies the idea of Bildung as part of their profile and mandate as hub festival. Following Klafki (1959[2001]), Bildung refers to processes of teaching and learning where human knowledge and cultural experience bodily and cognitively become part of the individual, including its critical, spiritual, and moral capacities. The festival organizers stress educational aims such as presenting the diversity of the country music genre for varied audiences, and they rig festival events such as the Opening Concert and Blågras partly as music lessons (Festival representative A 2014; Festival representative B 2014; fieldnotes and audio data July 2013, July 2014, July 2015). During Blågras 2015, one informal learning process, which is suited to exemplify a second result of musical gentrification, namely didactic cosmopolitanism, involved the American old-time musician, Riley Baugus, and the Blågras audience singing "Amazing Grace" together in a traditional manner (Baugus 2015, excerpt):

Baugus: I come from Southern Appalachia. I come from the Southern mountains of the United States, in the East Coast. And we have a very old tradition, which comes from Scotland. And we/ we line out songs. So I will/ I will give you the line, and you'll sing it back to me. Right? You can do this, trust me. Here we go! Go with me:

Amazing grace, how sweet the sound / That saved a wretch like me

Aud.: That saved a wretch like me / Baugus: I once was lost, but now I'm found 
Aud.: I once was lost, but now I'm found / Baugus: 'Twas blind but now I see

Aud.: 'Twas blind but now I see (...)

On stage Baugus shares stories about his background and culture. Using "Amazing Grace", originally an old Scottish hymn and later a well-known spiritual and country gospel standard, he educates the audience in traditional ways of singing and transmitting musical material. Trans-Atlantic rurality and religiosity surface during this segment. Through means of 'first person authenticity' (Moore 2002), that is one of integrity and unmediated narration, the musical cosmopolites in the audience temporarily become part of the global country music family, a transitory egalitarian community that transgresses difference. In this and the previous example involving "Coat of Many Colors", the music and applied forms of mediation speak to aspects of different yet shared nationhood, culture, and life circumstances. Hence, for audiences to engage in Blågras becomes a marker of socio-aesthetic distinction and a proper Bildung practice for the privileged, receptive individual as part of a larger historical and musical collective.

\section{Quality judgements and structural implications of musical gentrification}

The previous Minister of Culture, Anniken Huitfeldt (2015), stresses that Arts Council Norway (ACN) - not the Ministry - first assessed the artistic quality of the three festivals that applied for the country music hub status, and then nominated NCT as the preferred choice. Music experts in the Council were thus engaged as "cultural tastemakers and gatekeepers, tastekeepers" (Hovden and Knapskog 2014: 56 , emphasis in original). A few years later, ACN was again responsible for assessing NCT's fulfilment of the hub status criteria that concern artistic dimensions. The focus of scrutiny was placed both on the quality of the artistic expression and the mediation/performance of it, as well as on the degree of innovation and development in booking policies, live performances, and audience recruitment. The assessment mainly covered NCT's two initial years as a hub festival, 2012 and 2013 (ACN 2014).

As a relatively autonomous, visible and dominating expert institution in the Norwegian public sphere, the members and decisionmakers of ACN represent the cultural elite (Hovden and Knapskog 2014; Ljunggren 2014). They exert power over financial allocations as well as 'symbolic power' (Bourdieu 1979/2010) across many fields of arts and culture. The symbolic power manifests itself chiefly through recognitions of aesthetic quality. Hence, ACN contributes to definitions of what can pass as legitimate culture, for instance by judging what kind of music is of high quality and which festivals are credible. This symbolic recognition may in turn have beneficial economic consequences for cultural operators/agents.

As part of the assessment of the hub festival, external festival partners and cultural stakeholders were invited to comment on NCT's new position and achievements. Particularly, one dominant agent from the field of country music (source withheld for ethical reasons) made critical remarks on programme aspects and the fulfilment of the hub mission. Many of these remarks were included in $\mathrm{ACN}^{\prime}$ 's final assessment.

While ACN generally disapproves of the festival's predominant inclusion of "traditionally anchored expressions" and parallel exclusion of "contemporary and novel artists" (ACN 2014: 6, my translation), the report displays the influence of the 
external agent by use of verbatim renderings that highlight certain presumed consequences of NCT's malpractice:

The current situation does not contribute to increasing the interest in or the understanding of the country genre in Norway, but rather to upholding certain prejudices and stereotypes that over time have become attached to the genre. Following this view, the festival also cannot contribute as an artist competence centre for other festivals and organizers who advance country music in Norway. (ibid.: 8, my translation).

Moreover, ACN makes a point that while comparable to other Norwegian country music festivals, NCT has "the most conservative headliner choices" and "aspects of innovation and development are maintained to a very small extent" (ibid.: 9, my translation). Blågras, however, is recognized as a concept that offers "good qualities and credible performances" (ibid.: 9, my translation). Another argument set forth by the external agent and included word for word in ACN's final report stresses that:

The lack of Americana artists is of key significance, because this wide genre includes several country music innovators, provides a significant breadth of expressive forms, and artists in this genre to a substantial degree have contributed to developing interest in and understanding of country music in Norway for the last two decades. (ibid.: 7, my translation).

In sum, the full assessment illustrates how tastekeepers make quality judgements that generally favour the distinguished and discredit the popular. Although some forms of commercial and alternative country music on the festival programme, including party country, Norwegian bluegrass, and certain headliners from the US, are seen as relevant or credible in $\mathrm{ACN}^{\prime}$ 's assessment, the main message is that the required quality and legitimacy belong to country artists and festivals that are, unlike NCT, sufficiently innovative, original, willing to cross genre boundaries, and attuned for the kinds of refinement that musical gentrification processes necessarily incite.

Hence, one structural implication of musical gentrification and the associated symbolic supremacy of tastekeepers seems to be the relative inability of those being suppressed to influence cultural policy, specifically the quality standards that are decisive in interrelated matters of symbolic recognition and funding. The analysis above implies that the voice and music of grassroots participants are partly silenced and not fully acknowledged. In turn, this imbalance has consequences for cultural participation. Indeed, it seems to run counter to the ideological intentions of cultural democratization as traditionally suppressed groups still are being neglected by policies that do not manage to evade the power of legitimate middle and upperclass culture and taste. Among others, Mangset (1992: 89, my translation, emphasis in original) refers to optimistic culture politicians who speak in favor of "a democratization of culture, which means that the social imbalance in cultural participation is weakened as a result of an active cultural policy", instrumentally advocating the dissemination of high culture/fine arts to the masses and initiatives to overcome genre chauvinism (Henningsen 2015). In this context, a traditional country fan could very well say: "Chamber country music? Sorry, that's not my music" (fieldnotes 11 July 2014), and consequently, in line with general attendance trends at NCT, choose to opt out from concerts presenting refined country music (survey 2014). Hence, the intended inclusiveness of cultural policy can, as shown 
here, lead to the opposite: exclusion, further stigmatization, and social reproduction.

Another related implication of gentrification is reflected in the musical expressions of artists and the socio-aesthetic practices of audiences. I connect this to the aforementioned notion of didactic cosmopolitanism. Indeed, what previous research has labeled white-trash, redneck, and abject rurality (Fox 2004b; Solli 2006) is still celebrated at NCT. However, at the Blågras concerts affiliated musical traditions are reworked and refined in diverse ways. For instance the rural and significantly unknown, perhaps vulgar for some, have in a didactic manner been presented as the opposite for privileged participants. Low culture has been 'consecrated' (Bourdieu 1993; Halnon and Cohen 2006) and "elevated' into art" (Peterson 1997: 7), in this case triggered by the paradoxical cultural democracy/musical gentrification efforts of the Norwegian state. The festival's educational agenda and the learning potential of Blågras strategically answer to structural prescriptions related to quality, diversity, and democracy in cultural policy (as seen partially in ACN's assessment as well as in the hub mission white paper). Combined with the deep listening practices and openness of the present upper middle-class/elite audience, this creates an interconnected framework of educational profiles, political criteria and cultural practices that may be interpreted as a manifestation of didactic cosmopolitanism. Viewed as an outcome of musical gentrification processes, didactic cosmopolitanism provides a way for the well-off and the hip to take part in distinguished musical communities that carry informal and enriching learning potentials.

It is, however, important to note that this distinguishing practice and experiential frame did not replace traditional working-class festival activities at NCT, such as the outdoor main arena concerts where party country bands like Vassendgutane and American country artists perform. Attendees who typically engage in bodily listening were not displaced. During the period as a hub festival, Blågras was, rather, one of several additions to already existing concert formats and modes of aesthetic engagement. Nevertheless, in contrast to the democratic intentions of cultural policy, this study suggests that a class divide was reinforced after the granting of hub status. The different ways in which country music is staged, narrated and engaged with at Blag gras concerts and through, for instance, Vassendgutane's music, serve to highlight distinctions between omnivorous or cosmopolitan country fans and redneck country fans, between the elite and the common man.

\section{Conclusion}

NCT has long provided outdoor concerts at their main arena and indoor concept concerts at other locations. While the music performed at the main arena can generally be described as hard-core country, the music at for instance Blag gras was of a softer kind (cf. Peterson 1995[2004]).

Blågras was established in response to cultural policy criteria for hub institutions to promote artistic innovation. The music was explorative, mixing elements from different musical sources. At a Blågras concert the audience find themselves seated in an old barn. They engage in deep listening with room for reflection and learning. This live music setting and affiliated practices follow middle and upper-class social conventions. The educational level of the Blaggras audience is the festival's highest.

Twangy vocals and guitars dominate the soundscape of the main arena concerts. Party country hits invite the audience to sing along, dance, kiss, and have a good 
time. The musical and social become one through forms of bodily listening, much in line with traditional working-class modes of behaviour. The educational level of the main arena audience is the festival's lowest.

Looking at contemporary Norwegian society, the present study has shown that country music can be working-class, middle-class, and also elite culture. This became evident in the process of selecting and assessing NCT as a hub festival, as politicians and members of the cultural elite partook in musical gentrification initiatives that could change the popular festival into something more refined that better suited elite preferences. The habitus and cultural capital of the upper classes seem to resonate better with softer and explorative/hybrid forms of country music and aesthetic or deep modes of listening that reflect, for instance, didactic cosmopolitanism. The new Blågras concept echoes this point, and it was valued positively by ACN. The booking of headlining country acts at the festival was, however, described as conservative, lacking the valued aspect of innovation (ACN 2014).

In the field of (country) music, the good taste of some collides with the bad taste of others. Culturally privileged and powerful agents set quality standards that appear to enter cultural policy more easily than those of the less privileged, whose music is often devalued. This is problematic within a democratic cultural policy as public support and access to cultural activities become unevenly distributed, with the result that differences in status and recognition between popular and distinguished communities are reinforced and reproduced (Vestby 2017).

\section{Acknowledgements}

I sincerely wish to thank the reviewers and editors for valuable advice in the process of completing this article. Live Weider Ellefsen, Kai Arne Hansen and Håkon Larsen also deserve a great many thanks for providing important feedback, especially in the early stages of writing, as do the other members of the research group in Music Education and Cultural Studies at Inland Norway University of Applied Sciences. Among the members of the Musical Gentrification research group, I am particularly indebted to Sidsel Karlsen, Odd Skårberg and Petter Dyndahl for their continued advice and support. Finally, I wish to thank the festival organizers, as well as all other sources and performing artists at NCT who have shared their music, insights and experiences with me, and for permitting me to use interview statements in this research. The study which forms the basis of this article was funded by the Research Council of Norway and Inland Norway University of Applied Sciences.

\section{References}

Bibliography

ACN - Arts Council Norway -

2014. Vurdering av den Kunstneriske Måloppnå elsen til

Knutepunktinstitusjonene Norsk Countrytreff, Notodden Blues Festival,

Riddu Riđđu Festivá la og Øyafestivalen [Assessment].

2018. A Short Guide to Arts Council Norway.

https://www.kulturradet.no/english/vis/-/arts-council-norway-main Accessed:

2 January 2019. 
Angrosino, M. 2007. Doing Ethnographic and Observational Research. London: Sage.

Bourdieu, P. -

1979(2010). Distinction: A Social Critique of the Judgement of Taste. London and New York: Routledge.

1993. The Field of Cultural Production. Cambridge: Polity Press.

Brandstad, A. 2002. Kulturpolitikk og Populærmusikk. In J. Gripsrud Ed. Populærmusikken i Kulturpolitikken. Oslo: Norsk kulturråd: 259-292.

Ching, B. 2001. Wrong's What I Do Best: Hard Country Music and Contemporary Culture. New York: Oxford University Press.

Dyndahl, P. et al. 2014. Cultural Omnivorousness and Musical Gentrification: An Outline of a Sociological Framework and its Applications for Music Education Research. Action, Criticism, and Theory for Music Education 13 (1): 40-69. http://act.maydaygroup.org/articles/DyndahIKarlsenSkårbergNielsen13_1.pdf Accessed: 2 January 2019.

Dyndahl, P. et al. 2016. The Academisation of Popular Music in Higher Music Education: The Case of Norway. Music Education Research: 1-17. http://dx.doi.org/10.1080/14613808.2016.1204280

Fox, A. A. -

2004a. Real Country: Music and Language in Working-class Culture. Durham, N.C: Duke University Press.

2004b. White Trash Alchemies of the Abject Sublime. In C. Washburne and M. Derno Eds. Bad Music: The Music We Love to Hate. New York: Routledge: $39-61$.

Frith, S. 2004. What is Bad Music? In C. Washburne and M. Derno Eds. Bad Music: The Music We Love to Hate. New York: Routledge: 15-39.

Geertz, C. 1973. Thick Description: Toward an Interpretive Theory of Culture. In C. Geertz Ed. The Interpretation of Cultures. New York: Basic Books: 3-30.

Glass, R. 1963. Introduction to London: Aspects of Change. London: Centre for Urban Studies and MacGibbon \& Kee.

Halnon, K. B. and Cohen, S. 2006. Muscles, Motorcycles and Tattoos: Gentrification in a New Frontier. Journal of Consumer Culture 6 (1): 33-56. https://doi.org/10.1177/1469540506062721

Henningsen, E. 2015. Kulturpolitikkens Sedimentering: Kulturløftet som Kulturpolitisk Vekstperiode. Nordisk Kulturpolitisk Tidsskrift 18 (1): 28-40. https://www.idunn.no/nkt/2015/01/kulturpolitikkens_sedimentering_kulturloeftet som kulturpo Accessed: 6 January 2019.

Hovden, J. F. and Knapskog, K. 2014. Tastekeepers: Taste Structures, Power and Aesthetic-Political Positions in the Elites of the Norwegian Cultural Field. Nordisk Kulturpolitisk Tidskrift 17 (1): 54-75. https://www.idunn.no/nkt/2014/01/tastekeepers_taste structures power and aesthetic-politi Accessed: 18 January 2019.

Hubbs, N. 2014. Rednecks, Queers, and Country Music. Berkeley and Los Angeles: University of California Press.

Hylland, O. M. and Stavrum, H. 2018. 50 Years of Aesthetic Construction Work: The Music Policy of Arts Council Norway 1965-2015. In O. M. Hylland and E. Bjurström Eds. Aesthetics and Politics: A Nordic Perspective on How Cultural Policy Negotiates the Agency of Music and Arts. Cham: Palgrave Macmillan: 67-94. 
Jarness, V. 2015. Modes of Consumption: From 'What' to 'How' in Cultural Stratification Research. Poetics 53: 65-79. https://doi.org/10.1016/j.poetic.2015.08.002

Karlsen, S. 2007. The Music Festival as an Arena for Learning: Festspel i Pite $\ddot{A} / v d a /$ and Matters of Identity. PhD. University of Technology, Luleå. http://urn.kb.se/resolve?urn=urn:nbn:se:Itu:diva-17283 Accessed: 18 January 2019.

Klafki, W. 1959(2001). Kategorial Dannelse: Bidrag til en Dannelsesteoretisk Fortolkning av Moderne Didaktikk. In E. L. Dale Ed. Om Utdanning: Klassiske Tekster. Oslo: Gyldendal Akademisk: 167-203.

Korsnes, O. et al. Eds. 2014. Elite og Klasse i et Egalitært Samfunn. Oslo: Universitetsforlaget.

Kvalshaug, V. 2011. Countryfestival Må Snart Levere Kvalitet. Aftenposten, 5 September. https://www.aftenposten.no/meninger/i/P3n96/Countryfestival-masnart-levere-kvalitet Accessed: 9 January 2019.

Ljunggren, J. 2014. Finnes det en Norsk Kulturelite? In O. Korsnes et al. Eds. Elite og Klasse i et Egalitært Samfunn. Oslo: Universitetsforlaget: 193-210.

Malone, B. C. and Neal, J. R. 1968(2010). Country Music, U.S.A. Austin: University of Texas Press.

Mangset, P. 1992. Kulturliv og Forvaltning: Innføring i Kulturpolitikk. Oslo:

Universitetsforlaget.

2012. Demokratisering av Kulturen? Om Sosial Ulikhet i Kulturbruk og -

Deltakelse. Bø: Telemarksforsking.

Mann, G. 2008. Why Does Country Music Sound White? Race and the Voice of Nostalgia. Ethnic and Racial Studies 31 (1): 73-100. https://doi.org/10.1080/01419870701538893

Marcuse, P. 1985. Gentrification, Abandonment, and Displacement: Connections, Causes, and Policy Responses in New York City. Urban Law Annual; Journal of Urban and Contemporary Law 28: 195-240. https://heinonline.org/HOL/LandingPage?handle=hein.journals/waucl28\&div=6 \&id=\&page $=$ Accessed: 6 January 2019.

Meisingset, K. 2013. Kulturbløffen. Oslo: Cappelen Damm.

Moore, A. 2002. Authenticity as Authentication. Popular Music 21 (2): 209-223. https://doi.org/10.1017/S0261143002002131

Norwegian Ministry of Culture. 2011. Countryfestivalene Får Statsrådsbesøk. https://www.regjeringen.no/no/aktuelt/countryfestivalene-farstatsradsbesok/id651449/ Accessed: 6 January 2019.

Norwegian Ministry of Culture and Church Affairs. 2008. Knutepunkt: Kriterium for Knutepunktstatus og Vurdering av Gjennomføring av Knutepunktoppdraget. https://www.regjeringen.no/contentassets/14075506341f4f46b49dfb62440a4ca b/nn-no/pdfs/stm200720080010000dddpdfs.pdf Accessed: 6 January 2019.

OECD - Organisation for Economic Co-operation and Development. 2017. How's Life? 2017: Measuring Well-being. Paris: OECD Publishing. https://doi.org/10.1787/how_life-2017-en

Peterson, R. A. 1995(2004). The Dialectic of Hard-Core and Soft-Shell Country Music. Popular Music Analysis 3: 87-99.

1997. Creating Country Music: Fabricating Authenticity. Chicago: University of Chicago Press. 
2005. Problems in Comparative Research: The Example of Omnivorousness.

Poetics 33 (5): 257-282. https://doi.org/10.1016/j.poetic.2005.10.002

Peterson, R. A. and Kern, R. M. 1996. Changing Highbrow Taste: From Snob to Omnivore. American Sociological Review 61 (5): 900-907. http://doi.org/10.2307/2096460

Solli, K. 2006. North of Nashville: Country Music, National Identity, and Class in Norway. PhD. University of lowa, lowa City.

Storey, J. 2003. Inventing Popular Culture: From Folklore to Globalization. Malden, Massachusetts: Blackwell.

Szerszynski, B. and Urry, J. 2002. Cultures of Cosmopolitanism. Sociological Review 50 (4): 461-481. https://doi.org/10.1111/1467-954X.00394

Tichi, C. 1994. High Lonesome: The American Culture of Country Music. Chapel Hill: University of North Carolina Press.

Vestby, S. 2017. Folkelige og Distingverte Fellesskap: Gentrifisering av Countrykultur i Norge - en Festivalstudie. PhD. Inland Norway University of Applied Sciences, Elverum. http://hdl.handle.net/11250/2437613 Accessed: 2 January 2019.

Zimmerman, L. 2018. Bluegrass Beyond Borders - Darling West's Nordic Niche. Bluegrass Today, 19 April. https://bluegrasstoday.com/bluegrass-beyondborders-darling-wests-nordic-niche/ Accessed: 9 January 2019.

\section{Discography}

Dolly Parton. 1971. "Coat of Many Colors", Coat of Many Colors, CD, RCA, 4 October, USA.

Vassendgutane. 2005. "Granada", Ungkar med Dobbelseng [Bachelor with Double Bed], CD, Bare Bra Musikk, 6 April, Norway.

\section{Videography}

Moldestad, S. 2014a. "Coat of Many Colors" Blågras 2014 [Online video]. Available from: https://youtu.be/RyAt-JHN1R8 Accessed: 14 January 2019.

\section{Interviews}

Annlaug. 2015. Interviewed by Stian Vestby, Nordfjord, 5 March.

Bjørn. 2015. Interviewed by Stian Vestby, Nedre Eiker, 20 January.

Eirik. 2015. Interviewed by Stian Vestby, Bergen, 14 January.

Festival representative A. 2014. Interviewed by Stian Vestby, Nordfjord, 24 February.

Festival representative B. 2014. Interviewed by Stian Vestby, Nordfjord, 25 February.

Festival representative C. 2014. Interviewed by Stian Vestby, Nordfjord, 26 February.

Hilde. 2015. Interviewed by Stian Vestby, Nordhordland, 15 January.

Anniken Huitfeldt. 2014. Interviewed by Stian Vestby, Oslo, 10 November.

Kristian. 2015. Interviewed by Stian Vestby, Nordfjord, 7 March.

\section{Other sources}

Baugus, R. 2015. "Amazing Grace", Blågras, 11 July.

Moldestad, S. 2014b. Concert Introduction, Blågras, 12 July. 